\title{
The Architecture of Fauna in Turkey: Birdhouses
}

\author{
Hande Sanem Çinar ${ }^{1 *}$, Funda Yirmibeşoğlu ${ }^{2}$ \\ ${ }^{1}$ Department of Landscape Architecture, Faculty of Forestry, Istanbul University-Cerrahpaşa, Istanbul, Turkey \\ ${ }^{2}$ Department of Urban and Regional Planning, Faculty of Architecture, Istanbul Technical University, Istanbul, Turkey \\ Email: *saneme@istanbul.edu.tr
}

How to cite this paper: Çinar, H. S., \& Yirmibeşoğlu, F. (2019). The Architecture of Fauna in Turkey: Birdhouses. Current Urban Studies, 7, 551-561.

https://doi.org/10.4236/cus.2019.74028

Received: October 10, 2019

Accepted: November 15, 2019

Published: November 18, 2019

Copyright (c) 2019 by author(s) and Scientific Research Publishing Inc. This work is licensed under the Creative Commons Attribution International License (CC BY 4.0).

http://creativecommons.org/licenses/by/4.0/

\begin{abstract}
Throughout history, people have designed places, taking into account the absolute environmental factors and the needs of other living beings to live and to have shelter. Birds are primarily affected by changes in biodiversity and environmental conditions. Thus, people have built birdhouses, to prevent the decrease of bird population both in Turkey and in the world. As a matter of fact, birdhouses have historically had an important role in Turkish culture and art by reflecting sensitivities, delicate feelings and tastes of Turkish people. In this study, the history of birdhouses in Turkey and throughout the world is examined, examples of birdhouses in different spaces are mentioned, hence showing the importance and value of birdhouses for both the birds and the people of Turkey.
\end{abstract}

\section{Keywords}

Birds, Birdhouses, Turkish Culture and Tradition, Design

\section{Introduction}

The development of modern society in cities has recently led to rapid urbanization, which has significantly reduced the amount of green spaces (Furness \& Greenwood, 1993). However, large green areas in a city (parks, cemeteries, golf courses, wetlands and forests) play a significant role in urban biodiversity and provide the necessary conditions for a great range of bird species to live (Blair, 2004). Due to the gradual decrease in the number of green areas, birds began migrating to natural places. As for those who struggle to survive within cities, they started to build their nests on power poles, thus causing power cuts and bird deaths in increasing numbers. According to these circumstances, birdhouses have become vital for the survival and well-being of birds. 
The aim of this study is to examine and render historical details of natural and artificial birdhouses trying to survive in cities and natural places, and to call attention to and raise awareness about the sustainability of birdhouses. In line with this objective, the significance of birdhouses in Turkey is emphasized, and solutions are introduced in order not to lose the longstanding design perspectives and practices.

\section{History of the Birdhouses}

Birds have had a significant place in Turkish society since pre-Islamic times. They have always had place in Turkish culture, art, ethnography and folklore. The birdhouses, primarily built for little birds such as sparrows, goldfinches, pigeons, doves and storks, date back to very old times.

The first birdhouse dates to the $13^{\text {th }}$ century of the Anatolian Seljuks in Keykavus Darüşşifa (Hospital) in Sivas. The initial birdhouses were in the form of cavities, but it started to turn into a different form in the $16^{\text {th }}$ century, like a mansion or a palace by sticking out of buildings. Considering the historical process, it is noticeable that birdhouses are mostly common during, and after the Tulip Period (1718-1730). Some of the few birdhouses on the structures dating back to the foundation (1299-1451) and classical periods (1451-1703) of the Ottoman Empire are original, but some were built later. Old birdhouses in Istanbul and the other cities did not reach the current day due to natural disasters and collapses of buildings. For instance, the wooden birdhouses were destroyed as a result of naturally-caused fires (Akın, 2014).

Birdhouses can sometimes be built in the form of mosques, fountains, mansions and wooden houses, but they can sometimes be built in no certain architectural form. Sometimes there are birdhouses in different forms on the same building. The architectural elements used in the arches, domes, consoles and windows of these buildings reflect the unique stylistic features of the Classical and Baroque periods. Birdhouses built during the classical Ottoman period are mostly wooden houses, and they are remarkable with their double-decker structures and bay windows. The ornaments on birdhouses were attached great importance in the Baroque period as a result of Western artistic styles influencing the Turkish art. Dynamism, one of the distinct features of the Baroque style, was reflected on the facades of the birdhouses, and eave domes and consoles became the architectural elements that make the facades more dynamic (Url 1, 2019). Birdhouses may be seen on every kind of structure, but rather on places for worship and funerary chambers such as mosques or tombs, and structures belonging to the educational, commercial and domestic architecture which are subgroups of civil architecture.

In the western world, birdhouses are regarded as only architectural and artistic works or as maximally shelters for birds. Korkut (2009) states that the religion of Islam can be regarded as having the most prominent role in raising the awareness towards birds and build birdhouses. 
Our ancestors are in the belief that birds' ability to fly indicates their divine feature to reach God, and for that reason, they loved and respected these animals in awe and fear. Some certain beliefs and thoughts regarding them were transformed by the religion of Islam while some are still preserved as superstitious beliefs. Turkish people gave importance to the birds and treated them well as a result of all these beliefs and thoughts, and thus birdhouses appeared as a part of Turkish architecture (Aygün, 1994).

Both the Prophet Muhammed's love towards animals, and the hadiths and stories elaborating on animals in Islam improved this sensitivity. The dove, regarded as an innocent creature in Islam and symbolizing purity, clarity, peace and fraternity, represents the Holy Spirit in Christianity (Url 2, 2019). There is a common belief that the Prophet Muhammad (PBUH) was rescued from polytheists since a couple of pigeons built a nest and laid their eggs on the tree in the mouth of the cave while he was hiding in it. As a result, people helped birds build their nests and have shelter especially on religious structures (Url 3, 2019).

Gracious birdhouses have a unique and special place in Ottoman mosque architecture. Not only did they enable birds to have shelter, but they also prevent bird droppings from making mosque walls dirty and eroding stones due to the acid within. Thus, it is expected that people building bird houses will earn good deeds as long as birds take shelter in them (Ekinci, 2016).

The French traveler Jean de Thevenot, who traveled around the Ottoman Empire in the 17th century, wrote about birdhouses in his travel book: "Their benevolence embraces animals, especially birds. Many people go to markets to firstly buy and then release birds every day. They say that the souls of these birds will be witness to their goodness in the presence of the God on the Judgment Day". Moltke states in his book titled Briefeüber Zustände und Begebenheiten in der Türkeiaus den Jahren 1835 bis 1839 (Letters from Turkey) that Turkish people are beneficent even to animals. You come across a cat hospital in Uskudar, or there is a special place for nursing pigeons in the yard of the Bayezid Mosque. Troughs have been carved into the bases of many gravestones. When it rains, the troughs are piled up with water and serve as a poor but thirst-quenching menu for dogs and birds on a hot summer day. Muslims believe that the gratitude of animals will also bring goodness to the people (Url 4, 2019).

\section{The Examples of Birdhouses}

It is possible to classify birdhouses in two groups: The first group, and the most common, includes the ones designed as cells or cubbyholes sticking out the facades of buildings (UskudarAyazma Mosque, Eyup Shah Sultan Fountain). They resemble single-story manor houses which are in the form of bay windows, small structures in the shape of mansions, or multi-story palaces. Second group consists of the birdhouses in the form of cubbyholes which are carved into the facades of the buildings as alcoves (Url 5, 2019).

Birdhouses have four main functions: 
- Protecting eggs and offspring

- Providing necessary ambient temperature for growing eggs

- Being a kind of cradle for offspring

- Providing a perch for parents to be able to protect their offspring

Birdhouses need to consist of the three elements below to carry out these main functions:

- Invisibility as much as possible

- Inaccessibility as much as possible

- Impenetrability as much as possible

The best examples of structures on which old birdhouses can still be seen are Nevsehir Kursunlu Mosque Library, Taksim Maksem in Istanbul, Uskudar Ayazma Mosque, the Tombs of Sultan Mustafa III and Sultan SelimIII in Laleli, Selimiye Mosque and Eyup Shah Sultan School, and the Fountain of the Sheikh Ibrahim Tennuri in Kayseri (Aksoy, 2015). Mehmed Agha Mosque is one of the structures of the classical period. The structure, built by Davud Agha who was appointed as the chief architect after the great architect Sinan, embodies many birdhouses (Figure 1).

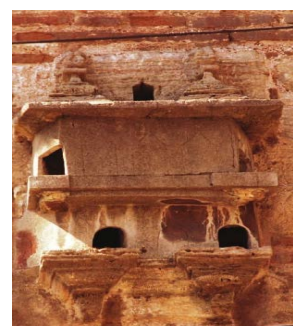

Emir Sultan Mosque, Bursa

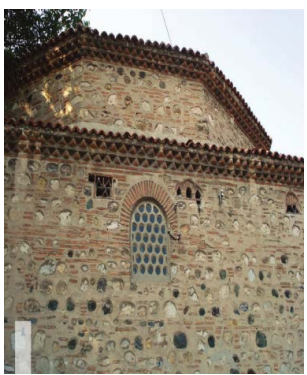

Tascilar Masjid, Manisa

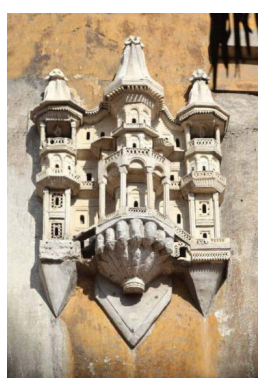

Ayazma Mosque, Uskudar, Istanbul

(Url 6, 2019)

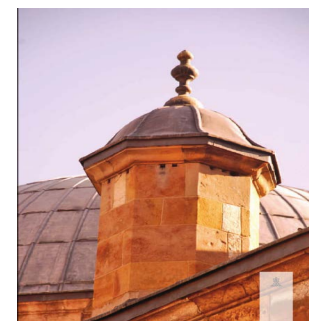

The Capanoglu Mosque, Yozgat

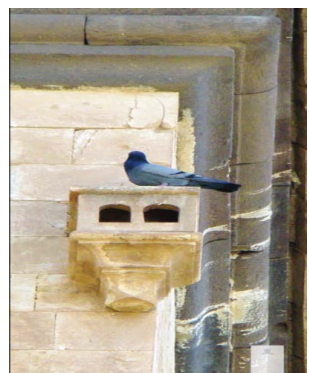

Ishak Pasha Palace, Agri

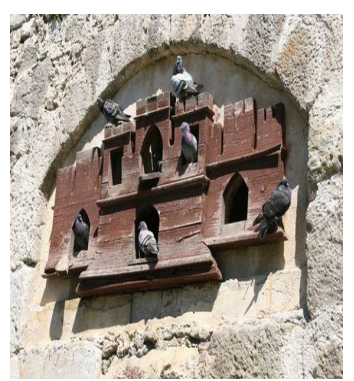

Bodrum Castle, Muğla

(Url 7, 2019)

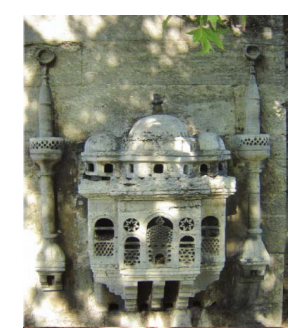

Yeni Valide Mosque, Uskudar, Istanbul

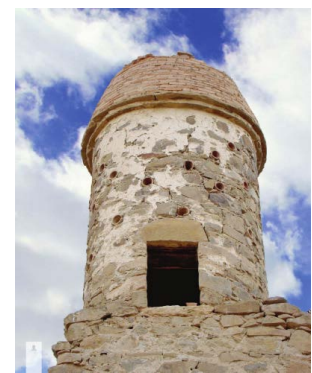

Hosap Castle, Van

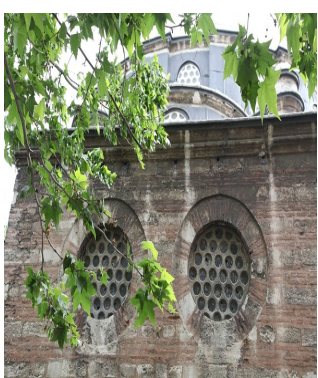

Mehmed Agha Mosque

(Url 8, 2019)

Figure 1. The examples of birdhouses from various cities (Avunduk, 2010). 
The aim of the birdhouses which Turkish people had built till the 19th century was to provide shelter for birds flying freely but being alone and vulnerable at the same time. In the old times, many birdhouses and hollow models were seen (Figure 2).

One of the most beautiful birdhouses is on the Ayazma Mosque in Uskudar, Istanbul. The catchy side of the structure, built by the Sultan Mustafa III, is to have birdhouses in various forms. There are two symmetrical birdhouses on consoles on the entrance facade of Istanbul Taksim Maksem, which was built by the Sultan MahmudI. Three-story birdhouse on the Fountain of the Sheikh Ibrahim Tennuri in Kayseri and the birdhouses on the tombs of Sultan Mustafa III and Sultan Selim III in Laleli, Istanbul are among other gracious examples (Aygün, 1994) (Figure 3, Figure 4).
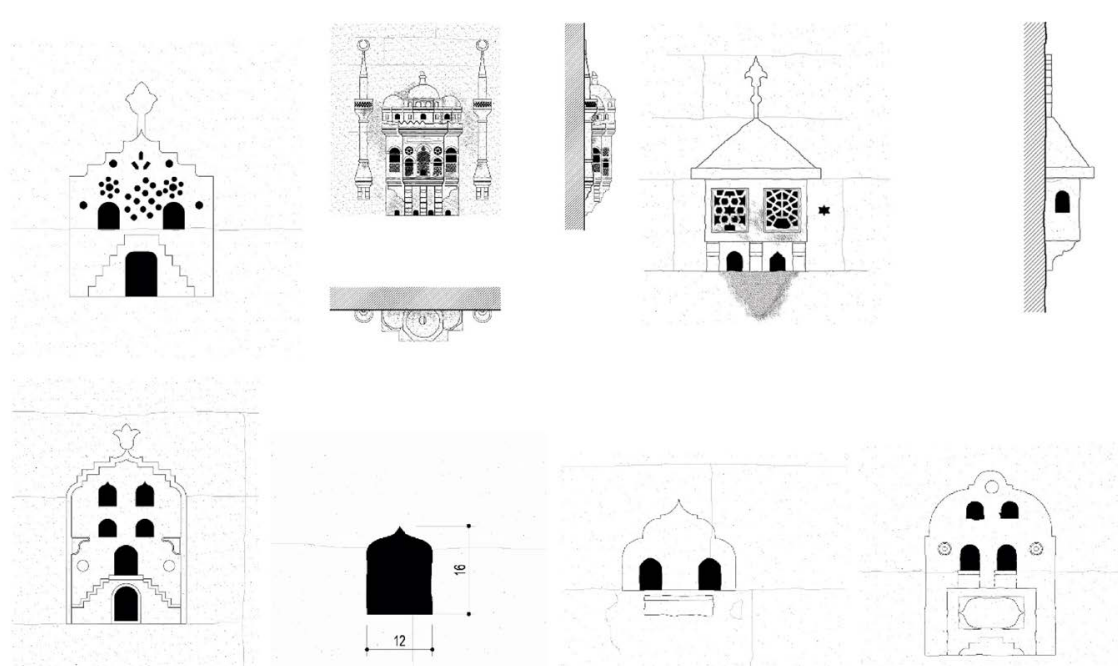

Figure 2. Various birdhouses and hollow models (Avunduk, 2010).

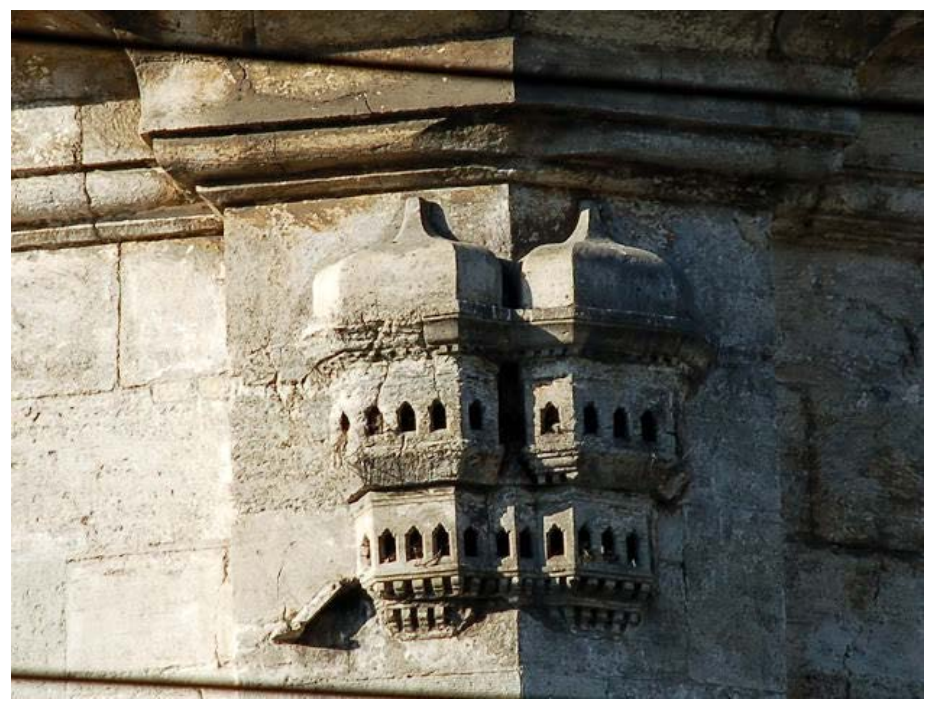

Figure 3. Laleli, Selim III and Mustafa III tombs (Url 9, 2019). 


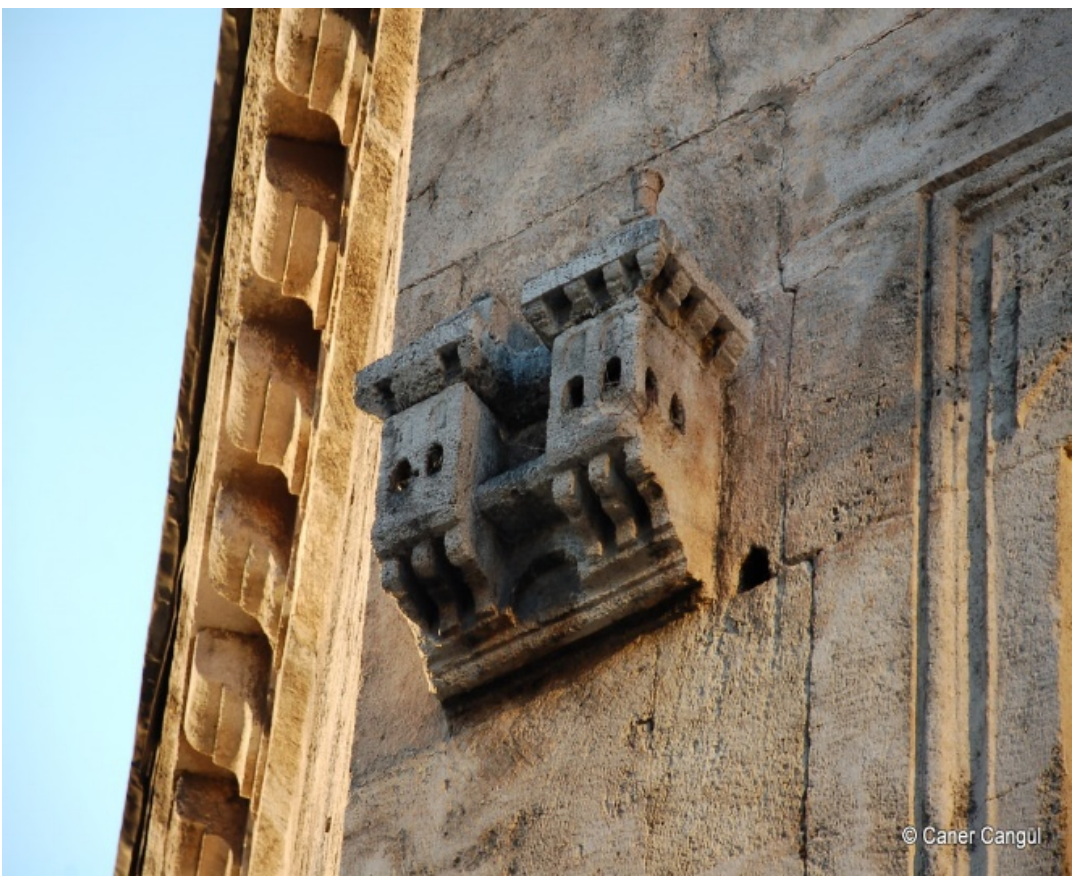

Figure 4. Taksim Maksemi (Url 10, 2019).

\section{Natural Birdhouses}

More than 10 thousand bird species in the world have evolved into a great range of forms to survive in different natural environments. There are differences in their sizes, lengths, appearances, and colors. They vary from ostriches which are very common in Africa and reach 2.5 meters in length to bee hummingbirds (named after their sizes) which are only found in Cuba. Some have an almost endless variety of species that challenge bird taxonomists.

Behaviors also greatly vary across birds, some of which are extremely social, and some of which are antisocial. In Africa, queleas and flamingos get together in flocks of millions while small parrots build parrot cities from branches (Url 11, 2019).

Birds are known as being the most skilled animals in nesting. Many criteria affect birds in choosing their nest sites. Having adequate food for themselves and their offspring, and having safe places to protect their eggs and raise their hatchlings are of vital importance. They need to sufficiently know breeding sites to detect, anticipate and avoid future threats (WWF Report, 2019).

The most important reason why birds build nests is that their eggs and hatchlings are uttermost vulnerable. Hatchlings need thermal-insulated nests which will prevent them from freezing. Especially "woven nests" can naturally provide desirable temperature for hatchlings, but it is difficult and exhaustive to build these kinds of nests. Female birds meticulously weave nests in a very long time and furthermore, they fill nests with feathers, threads and twigs by making them much more insulated. Birds use such materials as mud, leaves, ivies, feathers and papers to make these architectural masterpieces (Figure 5). 


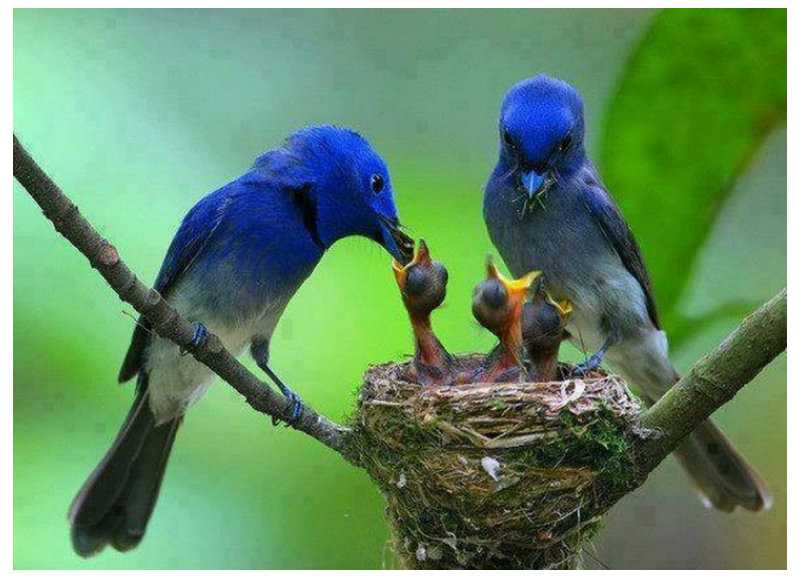

Figure 5. Netted birdhouse (Url 12, 2019).

Turkey abounds in bird species. Its geographical location in the Palearctic Region, its serving as a bridge over bird migration routes between Europe, Asia and Africa as well as its different climatic conditions and various habitats due to its rich topography can be ranked among the reasons for this abundance (Figure 6) (Kizilocak, 2017). For instance, doves build the simplest types of nests, and a nest can be made up of a piece of hay, sticks, tree cavities, etc.

\section{Birdhouses in the World}

Many beliefs, cultures and folks have attached importance to birds both in the past and today. However, if we put their aesthetical features aside, it is stated in the literature that the only cultures in the world which are suitable for birds to live together with people in cities are Turkish and Japanese cultures (Vatan \& Demir, 2019).

There are examples of different birdhouses in the world whose aesthetical features are at the forefront (Figure 7).

Of the studies conducted in Korea, one successful example is the Nest Pole designed by the South Korean Ryu Uiyoul and Kim Jihyun. The Nest Pole, which was designed in accordance with the idea that birds could build their nests on stone, concrete, iron and steel structures in a world where they continue losing their habitats as a result of rapid urbanization, enabled birds to live together with people and thus resolved the environmental problems of the modern world to a great extent (Figure 8) (Url 15, 2019).

\section{Conclusion and Evaluation}

An ordinary nest figure may come to many people's minds when they hear the word "birdhouse". But this is not the case. Each birdhouse indicates the refined taste of architects and can be comparable to palaces or mansions which are not only built for residing but also for architects to demonstrate their artistic talents. Perhaps, therefore, birdhouses are also known as "Bird Mansion" or "Bird Palace" (Url 16, 2019). 


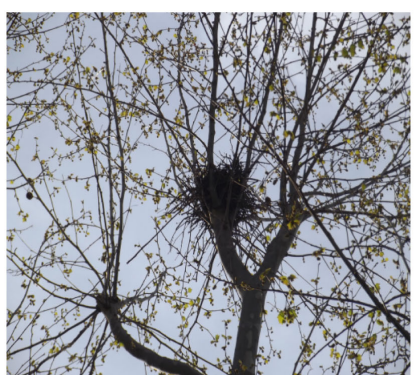

Abbasağa Park

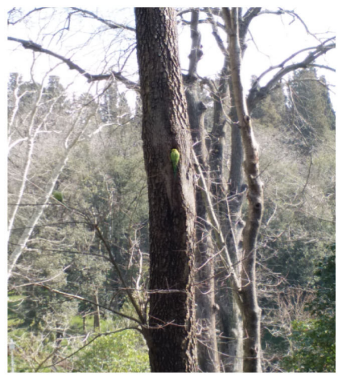

Yıldız Park

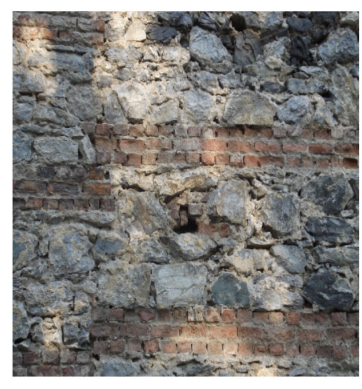

Yıldız Park

Figure 6. Birdhouses at natural places.
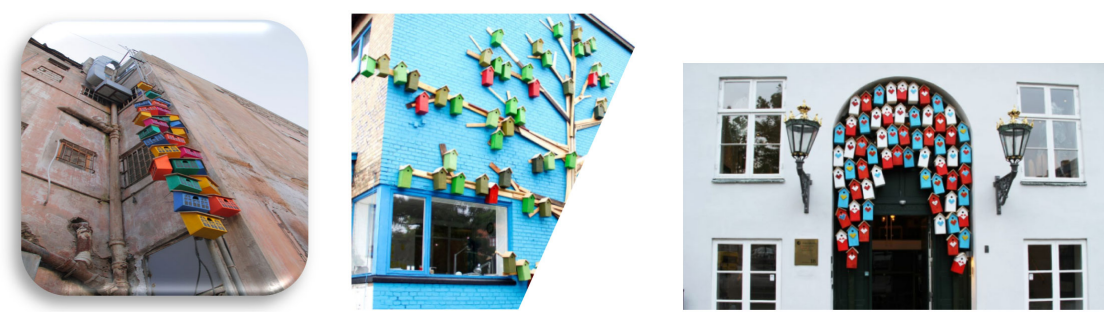

Happy City Birds Project, Kopenhag (Url 13, 2019)

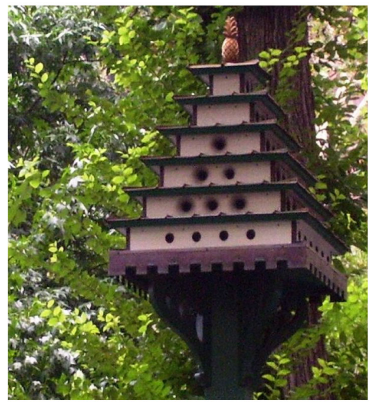

Gramercy Park, Manhattan, New York City

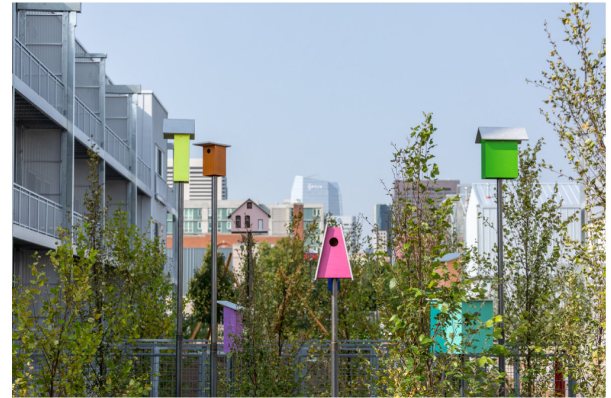

Denver, Colorado, ABD (Url 14, 2019)

Figure 7. Examples of birdhouses all around the world.

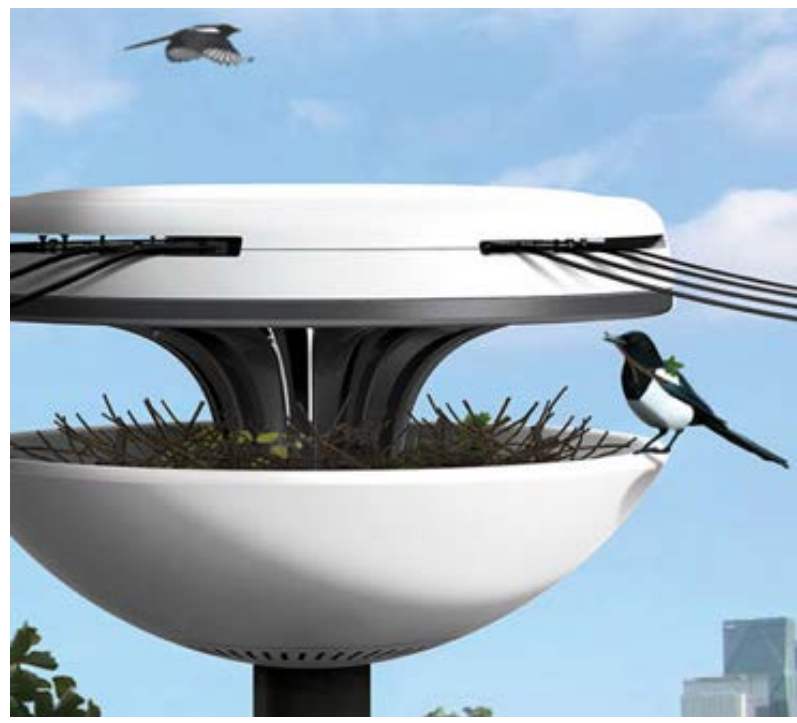

Figure 8. A modern design for a birdhouse (Nest Pole) (Url 15, 2019). 
Birdhouses today include all the sensitivities being formed around concepts such as "environmental awareness", "the culture of living together", "social responsibility", "sustainable development", "animal rights" and many others. Modern age adopts a fragmented perspective whereas "the awareness of tawhid" as being the central concept of Islam religion comprehends life as a whole (Türkan, 2018).

Birdhouses which were one of the details of our architecture in the past and have very few examples in our country now begin to be completely forgotten.

It is a fact that urban transformation changes and affects not only the lives of people but also the lives of all the living beings. In today's conditions, new settlements have influenced many factors in architecture as well as birdhouses. Most of the current birdhouses date back to the Ottoman times, and, unfortunately, new birdhouses are not built. Furthermore, some of the current birdhouses are at the risk of destruction, and even natural habitats for birds are intervened by people. It is obvious that the conditions of the birds and the places which will provide shelters for birds both in cities and in natural environments should be urgently reconsidered from an aesthetic and functional point of views. The current birdhouses should be restored, and new projects should be conducted for newer ones.

The Ottoman Empire as being known as its charitable foundations found its most gracious expressions in Istanbul architecture in 2017 with Vakif Participation Bank's social responsibility project about birdhouses and the design and photography competition for "Birdhouses". Reviving "birdhouses" thanks to a social responsibility project is a really positive process since birdhouses are one of the best works reflecting the Ottoman's life philosophy based on aesthetics and goodness. Carrying out such projects is thought to preserve cultural values, develop a sensitivity for environment while designing urban architecture and plans as well as strengthening the ties of people and other living beings. It will be the main objective to revive the tradition of building birdhouses as shelters for birds, to re-interpret and make people acquaint with the traditional forms in the light of today's needs and artistic approaches and ecologically contribute to the nature. In this regard, one of the best solutions would be to benefit from "popular culture" and "mass behavior".

\section{Conflicts of Interest}

The authors declare no conflicts of interest regarding the publication of this paper.

\section{References}

Akın, M. (2014). İstanbul Kuş Evlerive Özellikleri. Ankara: Ankara Üniversitesi Dil Ve Tarih Coğrafya Fakültesi Sanat Tarihi Bölümü Lisans Tezi.

Aksoy, N. (2015). Zarif İnsanlardan Kalan Bir Esinti 14 Maddeyle Kuş Evleri. https://listelist.com/osmanli-kus-evleri 
Avunduk, A. (2010). Şefkat Estetiği (pp. 181-193). İstanbul: Kuşevleri. Zeytinburnu BelediyesiKültür Yayınları-13 Ocak.

Aygün, Ü. (1994). Türk Mimarîsinin Minyatür Yapıları: Kuş Evleri (pp. 55-58). Tarihve Medeniyet 7, Eylül.

Blair, R. (2004). The Effects of Urban Sprawl on Birds at Multiple Levels of Biological Organization. Ecology and Society, 9, 2. https://doi.org/10.5751/ES-00688-090502

Ekinci, E. (2016). Merhamet Medeniyetinin Zarif Hâtıraları: Kuş Evleri. http://www.Ekrembugraekinci.com/makale.asp?id=762

Furness, R. W., \& Greenwood, J. J. D. (1993). Birds as Monitors of Environmental Change. London: Chapman \& Hall. https://doi.org/10.1007/978-94-015-1322-7

Kizilocak (2017). AnosDağı (Tekirdağ) Kuş Faunasının Araştırılması. Namık Kemal Üniversitesi Fen BilimleriEnstitüsüBiyolojiAnabilim Dalı, YüksekLisansTezi.

Korkut, Ş. (2009). İslâm Medeniyetinin Somutlaşan İnce Ruhu; Kuşevleri Örneği. İstanbul: Zeytinburnu Belediyesi Kültür Yayınları-131.

Türkan, H. (2018). Gönülden Gönüle Bir Yol: Kuşs. TohumSayı 161. https://t.co/yGDzUfoOIW

URL 1 (2019). https://tarihvemedeniyet.org/2014/05/kus-evleri.html

URL 10 (2019). Taksim Maksemi.

https://www.istanbulium.net/wp-content/uploads /2011/12/DSC_5319-1.jpg

URL 11 (2019).

http://nationalgeographic.com.tr/makale/ocak_2018/kuslar-neden-onemli/3928

URL 12 (2019). Örgü Kuş Yuvasi.

http://www.evrenvebilim.com/wp-content/uploads/2017/07/kuss-yuvaları.jpg

URL 13 (2019). https://thehundreds.com/blogs/content/the-key-to-gramercy-park

URL 14 (2019).

https://squabblog.wordpress.com/2011/08/23/urban-birdhousesculpture-on-the-high-li ne-in-new-york-city

URL 15 (2019).

http://smart.infoloji.com/post/42/modern-sehirlerde-guvenli-ve-estetik-kus-yuvalari/e $\underline{\mathrm{n} / \mathrm{en}}$

URL 16 (2019). https://efgan.tr.gg/Ku\&\%23351;-Evleri.htm

URL 2 (2019).

https://www.beyaztarih.com/resimlerle-tarih/detay/osmanlida-merhametin-sembolu-k us-evleri

URL 3 (2019).

https://www.fikriyat.com/kultur-sanat/2017/08/09/sevginin-kadim-mimarisi-kus-evleri

URL 4 (2019).

https://www.dunyabizim.com/mercek-alti/kus-evi-nedir-istanbulda-ilk-kus-evi-ne-za man-yapildi-h31704.html

URL 5 (2019). Birestetiğintarihçesi: Kușevleri, düșüncemektebi 31-10 2018. https://www.dusuncemektebi.com/d/170555/bir-estetigin-tarihcesi-kus-evleri

URL 6 (2019). https://tr.pinterest.com/pin/365987907197558275

URL 7 (2019). https://tr.pinterest.com/pin/733734964269010681

URL 8 (2019).

https://www.dunyabizim.com/gezi-mekan/istanbuldan-50-kus-evi-daha-1-h31690.htm $\underline{1}$ 
URL 9 (2019). Laleli, III. Selim-III. Mustafa Türbesi. https://www.istanbulium.net/wp-content/uploads/2011/12/DSC_6765.jpg

Vatan, A., \& Demir, Ö. (2019). Bird Palaces in İstanbul: Last Chance. Journal of Turkish Tourism Research, 3, 421-435. https://doi.org/10.26677/TR1010.2019.170

WWF Report (2019). Türkiye (Doğal Hayatı Koruma Vakfi), “Türkiye Üreyen Kuş Atlası" Ístanbul, Türkiye, Ocak 2019. 